\title{
Epilithic Diatoms Diversity in The Reservoir of Universitas Diponegoro, Semarang
}

\author{
Jihan Afiah ${ }^{a^{*}}$, Riche Hariyatia ${ }^{\text {, Tri Retnaningsih Soeprobowati }}{ }^{\mathbf{a}, \mathbf{b}, \mathbf{c}^{*}}$

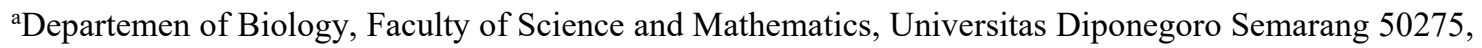 \\ Indonesia

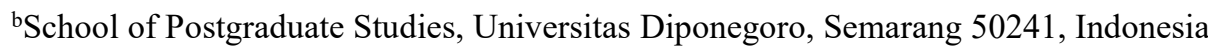 \\ *jafifah04@gmail.com , "trsoeprobowati@live.undip.ac.id \\ ${ }^{\mathrm{c} C e n t e r ~ f o r ~ P a l e o l i m n o l o g y ~(C P a l i m), ~ U n i v e r s i t a s ~ D i p o n e g o r o, ~ S e m a r a n g ~ 50241, ~ I n d o n e s i a ~}$
}

Received 21 May 2021

Accepted 20 June 2021

Published 30 June 2021

DOI: https://doi.org/10.51264/inajl.v2i1.8

\begin{abstract}
Diatom biodiversity is an increasing concern due to growing human impact, the study was carried out in one of the most important water storage reservoirs of Tembalang Region. The anthropogenic activity influence of diatom diversity in the UNDIP Reservoir. The reservoir of Universitas Diponegoro (UNDIP) Semarang was an area of $1.24 \mathrm{~km}^{2}$, with the deepest part of 15 meters, and able to accommodate water up to $13500 \mathrm{~m}^{3}$. This study aims to determine the relative abundance, diversity, evenness, dominance of diatoms and is expected to provide information about the condition of the waters in the Diponegoro University Reservoir, Semarang. Littoral benthic diatoms of five locations were sampled. Diatoms slides were prepared from scraping the rock surface with an area of $3 \times 3 \mathrm{~cm}$, dilute in $50 \mathrm{ml}$ distilled water, and identification under the microscope with 1000 magnification. Analysis of the physical characteristics of the waters includes Temperature, $\mathrm{pH}, \mathrm{DO}$, TDS, Conductivity, and Turbidity. The diatom composition in UNDIP Reservoir consists of 72 species that belong to 20 genera. The Shannon-Wiener diversity index $\left(\mathrm{H}^{\prime}\right)$ ranges from 2-3. The dominance index (D) ranges from $0.05-0.17$. The Evenness index (E) ranges from 0.54-0.90. Water quality parameters showed a fairly good value in the growth of diatoms. Dominated by periphytic taxa such as Cyclotella meneghiniana (15.72\%), Brachysira microcephala (9.93\%), and Achnanthidium minutissima (6.84\%) which are widely distributed and live at temperatures of $20-30^{\circ} \mathrm{C}$ and $\mathrm{pH}>6$.
\end{abstract}

Keywords: diatoms, diversity, evenness, dominance, UNDIP Reservoir

\section{INTRODUCTION}

The reservoirs are complex artificial aquatic ecosystems with functions as power plants, flood control, recreation, and various reservoirs that have been built for water storage during long periods of low water levels (fall-spring). The short residence time of water in reservoirs affects phytoplankton productivity and composition (Prado, 2002; Morais, 2017; Salusso \& Morana, 2018). A reservoir has potential biological resources. Semarang has 2 reservoirs, namely the Jatibarang and the UNDIP Education Reservoir. The function of the UNDIP Reservoir is intended to water stored, maintain the balance of the ecosystem and the environment including control flooding in the area around UNDIP Most of the domestic waste enters the reservoir that may induce pollution which harms public health.

As a relatively new reservoir, research at the UNDIP reservoir was limited. Secioputri (2014) studied water quality at the catchment area of Krengseng as a base for water quality management at UNDIP Reservoir. Research on diatoms has never been done in the UNDIP Reservoir, so the novelty of this research was the use of diatom as bioindicator water quality at UNDIP Reservoir. 
Diponegoro Reservoir is located in the Tembalang area, Semarang. This reservoir can accommodate normal water up to $478.24 \mathrm{~m}^{2}$ with a water catchment area of 7.13 hectare with a river length of $7.52 \mathrm{~km}$. The Diponegoro Reservoir functions to maintain the balance of the ecosystem and the environment, protect the area around the Tembalang UNDIP campus to avoid flooding, increase groundwater absorption as a conservation and recreation area (Setiadi, 2020).

Diatoms are microscopic organisms that belong to the Bacillariophyte Division. Diatom are well-known organisms, that able to live as planktonic or benthic form. Benthic diatoms can be separated based on the substrate, epiphytic for diatom lives at plants, epilithic - for diatom lives at the rock, epipelic - for diatom lives at the mud, and epizoic - for diatoms live at animals (Soeprobowati, 2020). Diatoms are called photosynthetic organisms because they contain chlorophyll a and chlorophyll-c. The most dominant pigments are caretenoid pigments (especially $\beta$-carotene, diadinoxanthin, and fucoxanthin), therefore diatoms can reflect a golden brown color (Round, 1993). Diatoms contribute $20-25 \%$ of oxygen production through photosynthesis (Mann, 1999).

Diatoms have a micro-sized silica shell with a nanoscale pattern and a frustule similar to photonic crystals and are capable of manipulating light (Tommasi, 2016; Rogato, 2020). Diatom frustules are amorphous nanoporous silicate cell walls that surround diatom cells and are used to classify diatoms. The frustule in diatoms provides mechanical stability and can protect diatoms from predators (Goesling, 2018). The availability of silica in diatom cells is an important point in diatom growth in nature. Silica deposits are influenced by the availability of nutrients in the sediment. Lack of silica content will stop the diatom cell cycle (Javaheri, 2015). The diatom frustule has a photonic structure and nano-scale pores when interacting with the light spectrum so the diatom can be identified (Goesling, 2018).

Diatoms are the dominant microalgae in almost all aquatic ecosystems and play an important role in the carbon cycle and food web (Soeprobowati et al., 2012). Diatoms are undoubtedly in response to changes to the environment because diatoms have wellpreserved cell walls in the sediment (Dixit et al. 1992; Gell et al. 2007; Reid \& Ogden, 2009; Soeprobowati et al., 2016; 2018; 2021). The diatom community is very responsive in responding to environmental changes such as $\mathrm{pH}$, nutrients, salinity, and also other environmental conditions. There are many diatoms used to indicate the water quality status of the lakes and paleoecology (Bere, 2014; Soeprobowati et al., 2016, 2021).

Diatoms are good indicators of changes in water use and quality. The most important feature is that diatoms can be present in all water surfaces, the samples collected from them can be maintained for a long time and can respond to environmental changes quickly (Tan, 2017). Nanopores in frustule can exchange gas, nutrients, and other metabolites (Lyakh, 2019). The diatom frustule can adjust the $\mathrm{pH}$ for $\mathrm{CO}_{2}$ absorption as a protection for the inside of the cell to connect with other cells in its survival (De Yuan, 2012).

The water quality in each area can be done by knowing the composition of the diatoms. Diatoms are capable to live even in extreme environmental conditions, the presence of diatoms is often well represented in benthic algal communities on high latitudes. The epilithic diatoms occupy the largest portion of river waters. The diatom has a very fast response to changes in the surrounding environment and has a short and fast life cycle compared to fish or other microinvertebrates. (Teittinen, 2016).

Epilithic diatoms are single-celled organisms that live attached to rock substrates (Soeprobowati, 2020). Epilithic diatoms are used for research purposes as suitable bioindicators (Teittinen, 2016). The rock substrate is moist and can be passed by environmental stressors, therefore epilithic diatoms are used as bioindicators that are sensitive to environmental conditions (Gowan, 2018). Epilithic diatom communities are considered more stable than epiphytic and epipelic communities, because of the stability of their substrates (Zelnik, 2020).

Diatom species promoted as bioindicator organisms are Cyclotella meneghiniana, Gomphonema lanceolatum is a bioindicator species in water that is not polluted or lightly polluted. Pinnularia gibba, Nitzschia sigmoidea, Nitzschia recta, Sellaphora bacillum are bioindicator species in moderately polluted waters. Fragilloria virescens, $F$. cappucina, Gomphonema ventricosum, Nitzschia palea, and Synedra ulna are bioindicator species in heavily polluted waters (Soeprobowati, 2001; Soeprobowati, 2010). 
Diatoms have a wide distribution throughout the world and are quick to respond to changes in the physical and chemical characteristics of water. (Kashima, 2008; Fitri, 2016). Diatoms, especially benthic diatoms, have a role as primary producers in the food chain. Benthic diatoms are used worldwide for water quality assessment. Benthic diatoms have taxonomic diversity and are resistant to changes in pollution and chemical, physical and biological disturbances (Chonova, 2019). Diatoms will respond to changes in water conditions in the form of abundance, the number of species, and colonization of certain taxa based on varying input of organic matter. Diatoms are used because diatoms are fast in responding to physical or chemical changes in the environment (Soeprobowati, 2010; Ananingtyas, 2018).
This study aims to determine the relative abundance, the indices of diversity, Evenness, and dominance of diatoms in the UNDIP researvoir in relation to the its water quality.

\section{METHODS}

This research was conducted in JulyDecember 2019. Sampling was carried out at the edge of the UNDIP Reservoir. The method used in this research is sampling to collect stone, measuring environmental parameters, collect diatoms from the stone, preparation, and identifying diatoms in the Ecology and Biosystematics Laboratory, Department of Biology, Faculty of Science and Mathematics, Universitas Diponegoro, Semarang

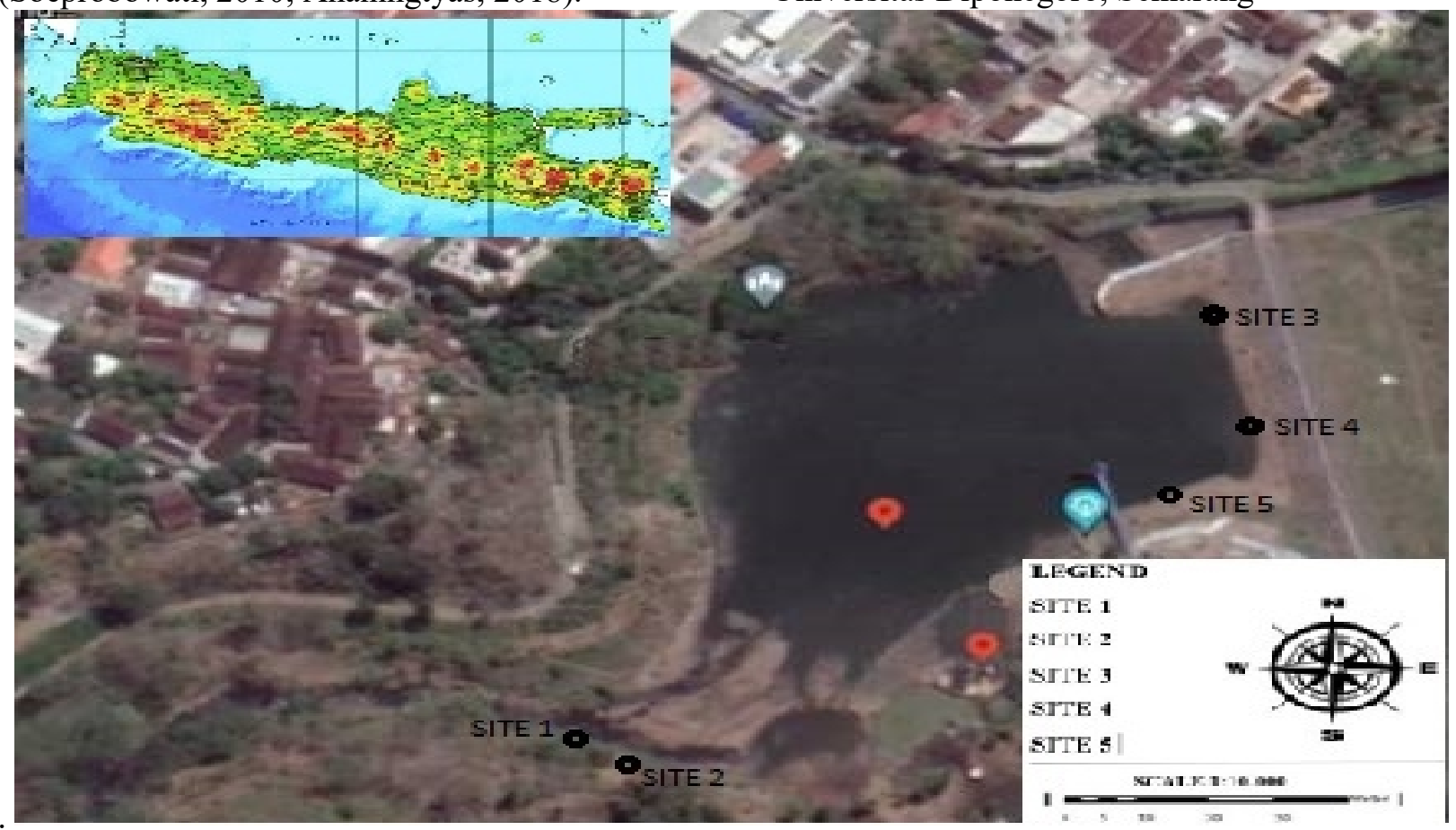

Figure 1. Study site in UNDIP Reservoir

Site 1 and 2 were a location that represents with inlet area and site 2 was dominated with vegetation of grass. Site 3 is the area near the bridge. Site 4 , is the side area near the outlet and represents the zone with full light. Site 5 represents an outlet (Figure 1.) Water quality parameters that are measured are temperature, salinity, dissolved oxygen, $\mathrm{pH}$, turbidity, conductivity, and total dissolved solids in the water. The water quality measurement used the HORIBA U-50 water checker.

The epilithic diatoms were collected on rock/cobbles that faced the water around 15 to 30 $\mathrm{cm}$ from the surface of the water using a hard- bristled toothbrush and glass tubes in the entire spring area, In the case of the reservoir, samples were collected from a different site.

The diatom sample was cleaned with a brush and rinsed with water, then washed using sodium hypochlorite and distilled water, and then centrifuged at a speed of 1,000 rpm for 5-10 minutes. Then identified diatoms under a microscope at 1,000 magnification.

Diatoms are identified using identification books Kramer \& Lange-Bernalot (2004), Gell et al (1999) and Taylor et al (2007), journals, and the web, namely algaebase.org, diatoms.org and westerndiatom. colorado .edu. 
To calculate the diatom abundance it can be expressed in individual $/ \mathrm{cm}^{2}$ (Magguran, 2004)

$$
N=\frac{V r}{V o} x \frac{n}{A}
$$

Where:

$\mathrm{N}$ : Total abundance (ind $/ \mathrm{cm}^{2}$ )

$\mathrm{V}_{\mathrm{r}}$ : Volume in sample vials $(\mathrm{ml})$

$\mathrm{V}_{\mathrm{o}}$ : The volume of one drop of sample water $(\mathrm{ml})$

$\mathrm{n}$ : Number of diatoms

A: Area of cranes $\left(\mathrm{cm}^{2}\right)$

The diversity index of diatoms, the ShannonWiener formula was used (Magguran, 2004)

$$
\mathrm{H}^{\prime}=-\sum_{i=1}^{n} p i \ln p i
$$

Where:

$\mathrm{Pi}=n \mathrm{ni} / \mathrm{N}$

ni : Number of individuals of type I

$\mathrm{N} \quad$ : The total number of individuals of all types

The criteria contained in this ShannonWiener are:

$\mathrm{H}^{\prime}<1 \quad$ : Low diversity level

$1<\mathrm{H}^{\prime}<3$ : Medium diversity level

$\mathrm{H}^{\prime}>3$ : High level of diversity

The evenness of the diatom type, it can be calculated using a formula (Magguran, 2004);

$$
E=\frac{H^{\prime}}{H m a k s}
$$

Where:

$\mathrm{H}^{\prime} \quad$ : Diversity index

Hmax : ln s (s: number of species)
Evenness index criteria

$$
\begin{array}{ll}
\mathrm{E}<0,4 & =\text { Low type evenness } \\
0,6 \geq \mathrm{E} \geq 0,4 & =\text { Medium type evenness } \\
\mathrm{E}>0,6 & =\text { High type evenness }
\end{array}
$$

The dominance of diatom types, was calculated with the formula (Magguran,2004);

$$
D=\sum\left(\frac{n i}{N}\right)^{2}
$$

Where :

$\mathrm{n}_{\mathrm{i}} \quad$ : Number of individuals to $\mathrm{i}$

$\mathrm{N}$ : The total number of individuals of all types

The criteria it has are;

$\mathrm{D}=0$ : the absence of predominant species or stable community structures

$\mathrm{D}=1$ : some species have dominated other species or community structures that change due to ecological pressures

\section{RESULTS AND DISCUSSION}

In total, 72 diatom epilithic taxa belong to 20 genera were found from UNDIP Reservoir (Figure 2). Eight dominant taxa exceeded a 2\% relative abundance (Achanthes 15.34\%, Achanthidium 3.42\%, Brachysira 12.60\%, Naviculla $13.00 \%$, Cyclotella $15.65 \%$, Gomphonema $16.40 \%$, Nitzchia $8.89 \%$, Pinnularia $8.52 \%$ ).

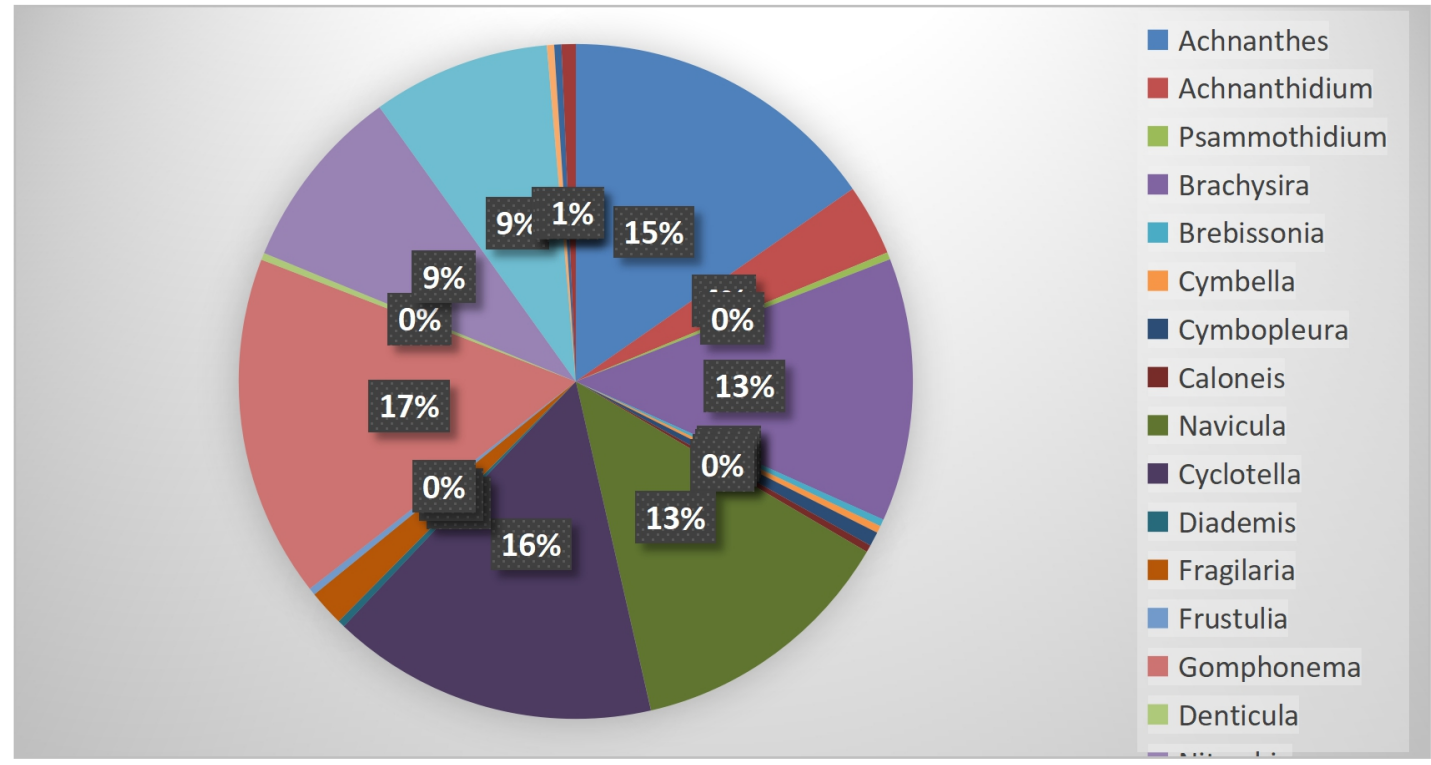

Figure 2. Diatom Abundance in UNDIP Reservoir 
Surface sediment assemblages of most diatom were dominated by Cyclotella meneghiniana (15.72\%), Brachysira microcephala (9.93\%), and Achnanthidium minutissima (6.84\%). Cyclotella meneghiniana can be found in a variety of habitats including eutrophic, and oligotrophic water. Cyclotella meneghiniana is often found because it has no means of movement and can be found in shallow water with high nutrient levels (Tanaka, 2007; Park, 2013). Cyclotella meneghiniana one of the planktonic diatoms that can be found all over the world and is widely distributed in lakes, rivers, seas, and brackish water (Vuuren,2006; Harmoko, 2018). Cyclotella meneghiniana can live in extreme environments because there is excess metal content and can reflect high resistance to pollutants, especially metal pollution (El-Bestawy, 2000). Cyclotella meneghiniana is a species that is tolerant of pollution and can represent the quality of waters that are rich in ionic concentrations (Venkatachalapathy, 2013).

Brachysira microcephala is a cosmopolitan species and can live at a pH of 5.9-6.6 (Vouilloud, 2014). Brachysira microcephala indicated in oligo saprobic to mesotrophic waters with a wide $\mathrm{pH}$ range also Brachysira microcephala can live in rivers and swamps with high water temperature, acidic $\mathrm{pH}$, and low conductivity (Vouilloud, 2014). Brachysira microcephala is considered a cosmopolitan species and widespread in Europe (Lange-Bertalot \& Moser 1994; Wolfe \& Kling 2001; Wojtal, 2003). Brachysira microcephala is reported from numerous freshwater habitats worldwide (Wojtal, 2003).

Achnanthes minutissima is a species found in the tropics, cosmopolitan and distributed at various altitudes and in almost all lakes (Bigler, 2002).

The abundance diatom in Site 1 and Site 2 (inlet area) was characterized by Gomphonema affine $\left(181 \mathrm{ind} / \mathrm{cm}^{2}\right)$ Pinnularia $s p . \quad(111$ ind $\left./ \mathrm{cm}^{2}\right)$, Gomphonema angustatum $\left(84 \mathrm{ind} / \mathrm{cm}^{2}\right)$. Species belonging to Gomphonema are relatively common in freshwater diatom communities. Gomphonema often forms branched mucilaginous stems attached to dense sub-strata. The genus Gomphonema is associated mainly with rocks and submerged vascular plants (Wojtal, 2003). Gomphonema angustatum, most of the diatom varieties in the reservoir inlet, are types commonly found in low water flows and stick to the substrate due to the shallow water inlet conditions and attached to vegetation. Gomphonema angustatum is a species that is resistant to pollution in these waters (Muscio, 2002; Xue, 2019).

The diatoms composition in Site 3, 4, and 5 (outlet area) was dominated by Cyclotella meneghiniana $\left(834 \mathrm{ind} / \mathrm{cm}^{2}\right), \quad$ Brachysira microcephala (195 ind $\left./ \mathrm{cm}^{2}\right), \quad$ Achanthes minuttisima (139 ind $\left./ \mathrm{cm}^{2}\right)$ Cyclotella meneghiniana is widespread in shallow, nutrientrich waters. (Horne and Goldman, 1994; Houk et al.,2010).

The difference in the total number of species abundance between inlet and outlet can be influenced by the presence of physiological processes, such as respiration and photosynthesis. The external factors that influence it are predation, turbulence, changes in salinity, and also turbidity (Odum,1998).

\section{Diversity, Evenness and Epilithic Diatom Dominance}

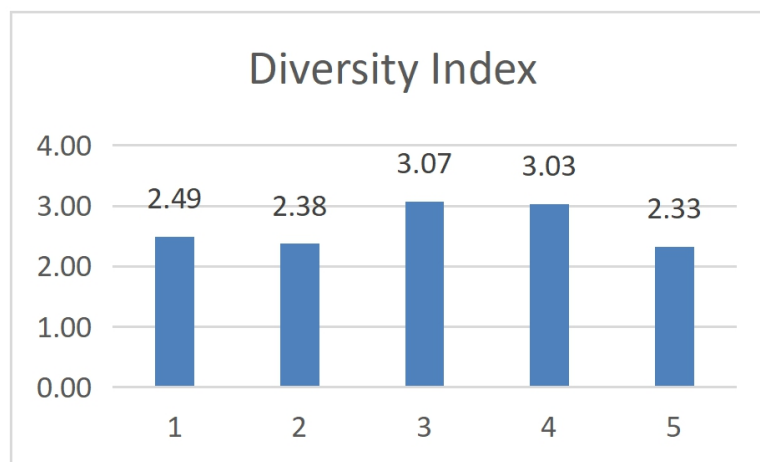

Figure 3. Shannon-Wienner Diversity Index in UNDIP Reservoir

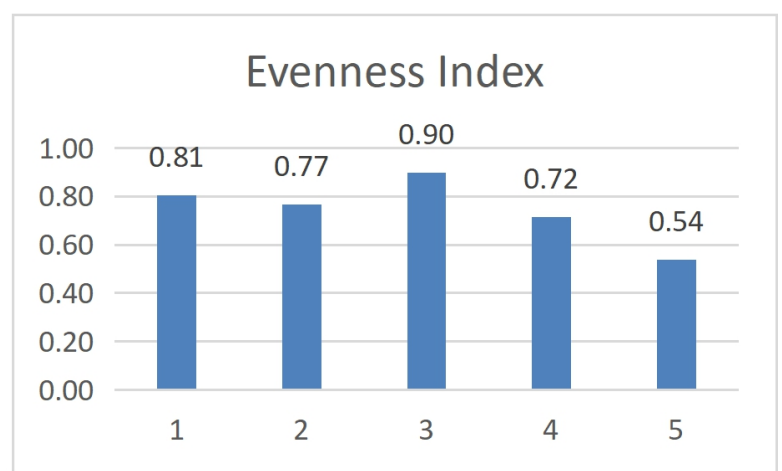

Figure 4. Evenness Index (e) in UNDIP Reservoir 


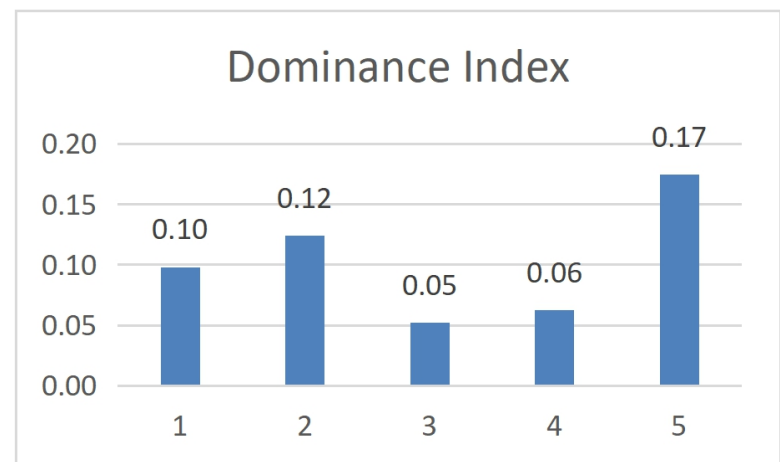

Figure 5. Dominance Index (D) in UNDIP Reservoir

Sites 1, 2, and 5 have a Shannon-Wiener diversity index with a range of 2.0-3 indicated that the ecosystem in these sites less stable. Sites 3 and 4 have a diversity value with a range of $>$ 3.0, indicated the ecosystem more stable.

The highest evenness value was at Site 3 (0.9) indicates that the uniformity between species is relatively the same and the number of individuals of each species is the same and the population is not dominated by a species. According to (Basmi, 2000; Pirzan 2005) if the evenness value approaches 0 then the evenness between species in a community is low. The evenness value that is close to number 1 , then the evenness between species in a community is relatively even or the same.

The highest dominance index was at Site 5 (0.17) indicate many species and no species dominate other species (Dash, 2001). Dominance index is used to describe species that dominate other types (Yuliana, 2012).

\section{Water quality}

The site shows the heterogeneity of temperature, $\mathrm{pH}$, dissolved oxygen, turbidity, Total Dissolved Solution, and conductivity values. The results of water quality measurements are as follows as shown in Figure 6-11.

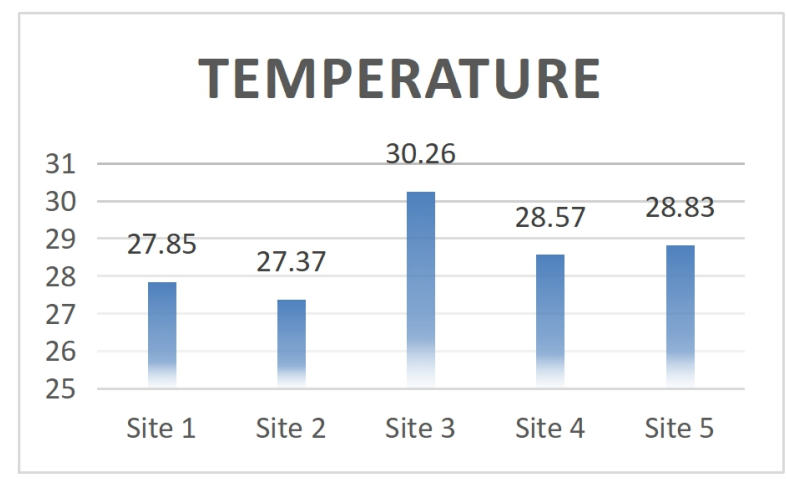

Figure 6. Temperature Value of the Reservoir UNDIP

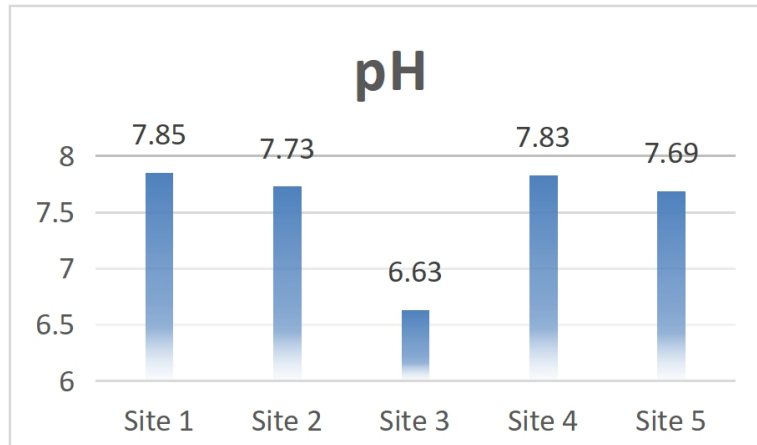

Figure 7. $\mathrm{pH}$ Value of the Reservoir UNDIP

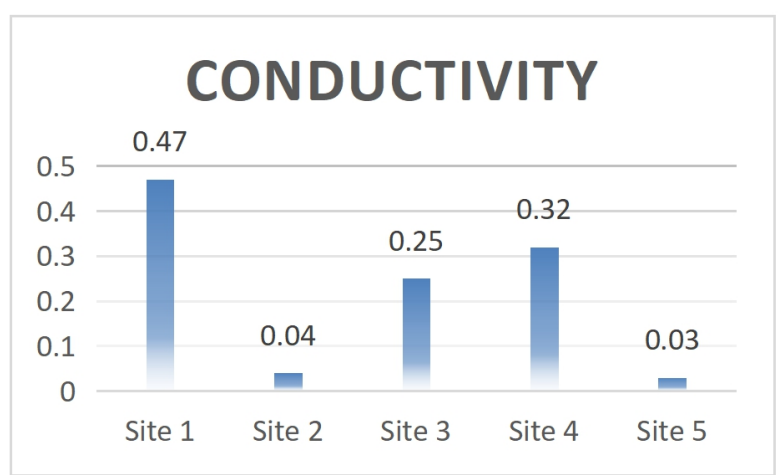

Figure 8. Conductivity Value of the Reservoir UNDIP

\section{TURBIDITY}

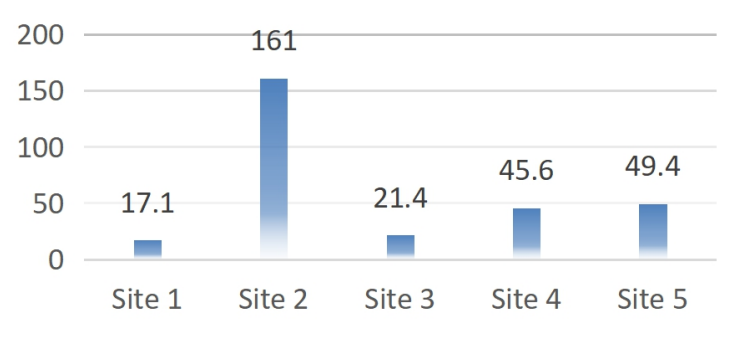

Figure 9. Turbidity Value of the Reservoir UNDIP

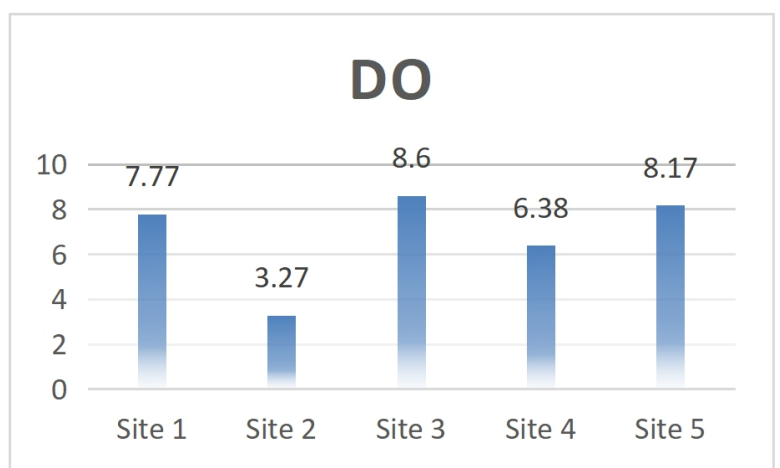

Figure 10. DO Value of the Reservoir UNDIP 


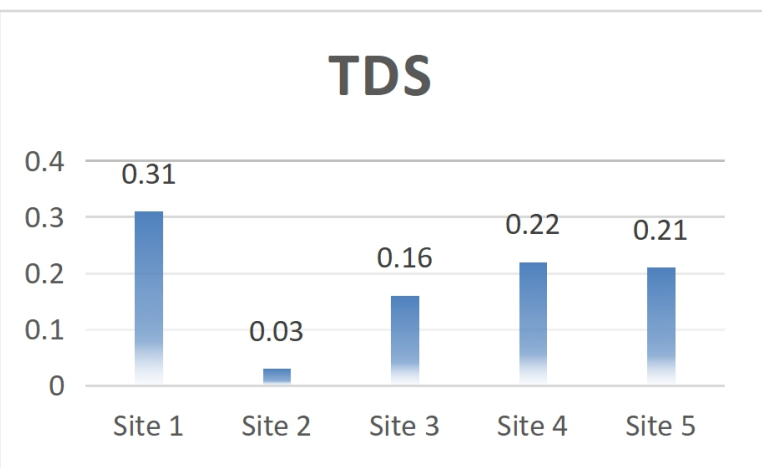

Figure 11. TDS Value of the Reservoir UNDIP

Site 3 has the highest species diversity with the has a water temperature value of $30.26^{\circ} \mathrm{C}, \mathrm{pH}$ of $6.63, \mathrm{DO}$ of $8.6 \mathrm{mg} / \mathrm{L}$, these are the most suitable for diatom growth. Effendi (2003) stated that the temperature of $20-30^{\circ} \mathrm{C}$ is still good for the growth and photosynthesis of diatoms. The $\mathrm{pH}$ value has followed the class I water quality standard based on Government Regulation No. 82 of 2001 which is in the range of 6-9. The dissolved oxygen content in the waters is less than $2 \mathrm{mg} / \mathrm{L}$, which can cause death in aquatic organisms (Enawaty, 2011).

The lowest diversity was found at Site 5 which indicated the presence of the dominating species. Cyclotella meneghiniana is the most common species and is compatible with the water conditions at Site 5. Cyclotella meneghiniana with maximum abundance in lakes with $\mathrm{pH}>6.0$ and maximum growth at water temperatures of $13-28^{\circ} \mathrm{C}$ (Mitrovic, 2010).

\section{CONCLUSION}

There are 72 types of diatoms identified from the UNDIP Reservoir. The diversity index includes 2-3 medium-high categories. The evenness index ranged from 0.54-0.90 and the dominance index ranged from $0.05-0.17$, which means that no species dominates. Water quality parameters showed a fairly good value in the growth of diatoms. Dominated by periphytic taxa such as Cyclotella meneghiniana, Brachysira microcephala, and Achnanthidium minutissima which are widely distributed and live at temperatures of $20-30^{\circ} \mathrm{C}$ and $\mathrm{pH}>6$.

\section{ACKNOWLEDGEMENTS}

The authors thank to Kenanga Sari, Riana Dewi, Siti Nur Jannah, Christopher Hardian, Safira Rosyada, Oki Rachmalia, and Syahfitri Dwi Yansi for their support in conducting field and laboratory works.

\section{REFERENCES}

Agustina, S.S., A. A. M. Poke. 2016. Keanekaragaman Fitoplankton Sebagai Indikator Tingkat Pencemaran Perairan Teluk Lalong Kota Luwuk. Jurnal Balik Diwa. 7 (2).

Antoniades D., Douglas M.S.v., and Smol J.P. 2009. Biogeographic Distributions and Environmental Controls of Stream Diatom in the Canadian Aretic Archipelago. BotanyBotanique, 87, 443-454.

Aprisanti, R., A. Mulyadi., S. H. Siregar. 2013. Struktur Komunitas Diatom Epilitik Perairan Sungai Senapelan dan Sungai Sail, Kota Pekanbaru. Jurnal Ilmu Lingkungan. 7(2)

Basmi, J. 2000. Planktonlogi: Plankton sebagai Indikator kualitas perairan. Fak. Perikanan dan 1lmu Kelautan. Institut Pertanian Bogor, $60 \mathrm{pp}$.

Bere T. 2014. Ecological Preferences of Benthic Diatoms in a Tropical River System in São Carlos-SP, Brazil. Tropical Ecology. 55(1), 47-61.

Bigler, C., and Roland, I, H. 2002. Diatoms as Indicators of Climatic and Limnological Change in Swedish Lapland: a 100-Lake. Calibration Set and Its Validation For Paleoecological Reconstructions. Journal of Paleolimnology. 27, 97-115

Bold, H. \& M.J. Wynne. 1985. Introduction to The Algae 2nd Edition. Prentice Hall-Inc: New Jersey. 154 pp.

Cholik, M., Artati dan R. Arifuddin. 1988. Pengelolaan Kualitas Air Kolam Ikan. Direktorat Jendral Perikanan Bekerjasama dengan International Development Research Center. Jakarta.

Chonova, T., et al., 2019. Benthic Diatom Communities in an Alpine River Impacted by Waste Water Treatment Effluents as Revealed Using DNA Metabarcoding. Front Microbiology. 10, 653pp 
Dash, M. C. 2001. Fundamentals of Ecology. $2^{\text {nd }}$ ed. New Delhi (IN): Tata McGraw-Hill

De Yuan, Z., et al., 2012. Bio-Manufacturing Technology Based on Diatom Micro- and Nanostructure. Chinese Science Bulletin. 57(30), 3836-3849

Dixit SS, Smol JP, Kingston JC, Charles DF. 1992. Diatoms: Powerful Indicators of Environmental change. EnvironSciTech. 26(1), $23-32$.

Effendi, H. 2003. Telaan Kualitas Air Bagi Pengelola Sumber Daya dan Lingkungan Perairan. Yogyakarta:Kanisius.

El Bestawy, E. 2000. X-Ray Microanalytical Study on Cyclotella meneghiniana (Bacillariophyceae) as a Bio-indicator for Metal Pollution in Marine and Fresh Water Environments. Pakistan Journal of Biological Science. 3(9).

Ernawaty, S. Saenab and Rabanai. 2011. Komposisi Jenis Zooplankton di Perairan Sungai Je'neberang Sungguminasa Kec. Somba Opu Kab. Gowa. Bionature. 12(1), 3539.

Faizin, K. Ahsanul., S. Rudiyanti., S. Anggoro. 2018. Profil Status Kesuburan Perairan Secara Vertikal di Waduk Jatibarang, Semarang. Journal of Maquares. 7(2), 197-206.

Fitri, W. Elsa. 2016. Variasi Morfologi Diatom Epilitik Sebagai Indikator Lingkungan Pada Kisaran Salinitas Berbeda Di Perairan Bandakali Dan Lubuk Mintirun. Jurnal IPTEKS Terapan. 9(3).

Fitriyah, Yaya., B. Sulardino dan N. Widyorini. 2016. Struktur Komunitas Diatom Di Perairan Tandon Air Untuk Tambak Garam Di Desa Kedung Mutih Kecamatan Wedung, Demak. Jurnal of Maquares. 5(2).

Gell P, Tibby J, Little F, Baldwin D, Hancock G. 2007. The impact of Regulation and Salinisation on Floodplain Lakes: The Lower River Murray, Australia. Hydrobiologia. 591(1), 135-46.

Goessling, J. W., Su, Y., Cartaxana, P., et all. 2018. Structure-Based Optics of Centric Diatom Frustule: Modulation of the in vivo Light Field for Efficient Diatom Photosynthesis. New Phytologist. 219(1),122134.
GowanMc.S. et all. 2018. Functional Attributes of Epilithic Diatoms for Paleoenvironmental Interpretations in South- West Greenland Lakes. Journal Paleolimnol. 60.

Hamuna, B., R. H.R. Tanjung, et all. 2018. Kajian Kualitas Air Laut danIndeks Pencemaran Berdasarkan Parameter FisikaKimia Di Perairan Distrik Depapre, Jayapura. Jurnal Ilmu Lingkungan. 16(1).

Harmoko dan Y. Krisnawati. 2018. Mikroalga Divisi Bacillariophyta yang Ditemukan di Danau Aur Kabupaten Musi Rawas. Jurnal Biologi Universitas Andalas. 6(1).

Houk, V., Klee, R., Tanaka, H.2010. Atlas of freshwater-centric diatoms with a brief key and descriptions, Part III. Stephanodiscaceae A. Cyclotella, Tertiarius, Discostella Fottea 10(Supplement):1-498

Horne, A. J and C. R, Goldman. 1994. Limnology. Second edition. Mc Graw-Hill. Inc. New York. 193-432pp

Javaheri, N., R. Dries, A. Burson, L. J. Stal, P. M. A. Sloot and J. A.Kaandorp. 2015. Temperature Affects the Silicate Morphology in a Diatom. Scientific Reports. 5,1-9.

Kadim, M.K., Pasisingi, N., dan Paramata, A.R. 2017. Kajian kualitas perairan Teluk Gorontalo dengan menggunakan metode STORET. Depok, 6(3),235-241.

Kashima, K. 2008. An Application of Diatom Analysis for Environmental Monitoring at Mangrove and Lagoon Areas in South-East Asia. Department of Earth and Planetary Sciences, Kyushu University, Jepang

Krompkamp, J ; Barranguet, Christianne \& Jan Peene. 1998. Determination of microphytobenthos DSII quantum and photosynthetic activity by means of variable chlorophyll fluorescene. Mar. Ecol. Prog. Ser., 162:45-55. Pengembangan Oseanolog LIPI. Jakarta

Lange Bertalot., H. \& Moser G. 1994. Brachysira. Monographie der Gattung. Bibliotheca Diatomologica 29. J. Cramer, Berlin Stuttgart.

Lee, S.D., J. S. Park and J. H. Lee. 2013. Taxonomic Study of the Genus Achnanthes 
(Bacillariophyta) in Korean Coastal Waters. Journal of Ecology and Environment. 36(4).

Lowe, R. Loren. 1970. Taxonomic and Ecological Analyses of Diatom Communities in Drainage Ditches. Theses and Dissertations. Iowa State University Capstones.

Lyakh, A. M., Yekaterina. D. B., Olga. V. S. 2019. New Method of Estimation of the Relative Area of Perforations on Valves of Centric Diatoms Using SEM Images on the Example of Minidisus vodyanitskiyi Lyakh et Bedoshvili. Ecologica Montenegrina. 21, 4652

Magurran, A. E. 2004. Measuring Biological Diversity. Blackwell Science Ltd. The United Kingdom.

Mann, D. G. 1999. The Species Concept in Diatoms. Phycologia. 38(6), 437-495

Mawarni, A., Hadisusanto, dan Suwarno. 2019. Distribusi Dan Kelimpahan Plankton Di Wet DuneSlacks Gumuk Pasir Parangtritis, Bantul, DIY. Biospecies. Vol 12 No 1. Page: 77-89

Mitrovic, S. M., J. N. Hitchcock., A. W. Davie., and David A. Ryan. 2010. Growth responses of Cyclotella meneghiniana (Bacillariophyceae) to various temperatures. Journal of Plankton Research. 32(8).

Morais, D. L. 2017. Assessment of Disturbance at Three Spatial Scales in Two Large Tropical Reservoirs. Journal Limnology. 76(2), 240252

Murni, M. Y. 2020. Epilithic Diatom Abudance Study in the Batang Kuranji River in Padang City, West Sumatra. Advances in Tropical Biodiversity and Environmental Sciences. 4(2), $39-43$.

Muscio, C. 2002. The Diatom Pollution Tolerance Index. Watershed Protection and Development Review Departement, Environmental Resource Management Division: Austin, TX, USA.

Nedi, S. 2001. Produktivitas Muara Sungai Siak ditinjau dari Kandungan Fosfat, Nitrat danKelimpahan Fitoplankton. Jurnal Perikanan dan Ilmu Kelautan. 6(2), 86-93.

Nontji, Anugerah. 2008. Plankton Laut. LIPI Press. Jakarta.
Odum EP. 1971. Fundamentals of Ecology. WB. Saunders Company. London.

Odum, E. P., 1998. Dasar-dasar Ekologi (Fundamentals of Ecology). Transleted by: $\mathrm{Tj}$. Samingan. Gajah Mada University Press. Yogyakarta.

Park, J. S, Sang D. L, and Jin H. L. 2013. Taxonomic Study on the Euryhaline Cyclotella (Bacillariophyta) Species in Korea. Journal of Ecology and Environment. 36(4), 1-13.

Pirzan, A. M , Utojo., et all. 2005. Potensi Lahan Budi Daya Tambak dan Laut di Kabupaten Minahasa Sulawesi Utara. Jurnal Penelitian Perikanan Indonesia. 11(5).

Prado, R. B. 2002. Manejo Integrado de Rservatorios Destinados a Uso Multiplo Como Perspectiva de Recuperacao da Qualidade da agus Integrado (Book in Portuguese)In: Recursos Hidroenergeticous: usos, impactos e planejamento. RIMA, Sao Carlos. 360pp

Prygiel dan A. J. Horne. 1999. Limnology. McGraw Hill International Book Company. NewYork

Purnomo, A. Arifiani., I Ketur Junitha dan Ni Made Suartini. 2015. Variasi Spesies Diatom pada Tipe Perairan Berbeda Untuk Kepentingan Forensik Sebagai Petunjuk Kematian Akibat Tenggelam. Jurnal Simbiosis. 3(1).

Reid MA, Sayer CD, Kershaw AP, Heijnis H. 2007. Palaeolimnological evidence for submerged plant loss in a floodplain lake is associated with accelerated catchment soil erosion (Murray River, Australia). Journal Paleolimnol. 38, 191-208.

Rogato, A. and E. D. Tommasi. 2020. Physical, Chemical, and Genetic Techniques for Diatom Frustule Modification: Applications in Nanotechnology. Applied Sciences. 10.

Round, F. E. 1990. The Diatoms. $1^{\text {st }}$ edition. Cambridge University Press. New York.

Setiadi, W., Bandi, S., Fauzi, J. A. 2020. Studi Deformasi Waduk Pendidikan Diponegoro Tahun 2019. Jurnal Geodesi UNDIP. 9(1).

Soeprobowati, T.R., Suedy. S.W.A. 2010. Komunitas Diatom pada Ekosistem Mangrove 
Pantai Utara Jawa Tengah. Jurnal Sains \& Matematika. 18(3), 94-102.

Soeprobowati, T.R., S. Djalal. T., Sutikno. S. H., and Peter. G. 2016. The Minimum Number of Valves for Diatom Identification in Rawapening Lake, Central Java. Biotropia. 23 (2), 96-104.

Soeprobowati TR, Suedy SWA, Gell P. 2012. Diatom stratigraphy of mangrove ecosystems on the northern coast of Central Java. Journal of Coastal Develpopment. 15(2), 197-208.

Suwartinah, Ken. Widianingsih, R. Hartati dan S. Y. Wulandari. 2011. Komposisi Jenis dan Kelimpahan Diatom Bentik di Muara Sungai Comal Baru Pemalang. Ilmu Kelautan. 16(1).

Syafarina, R, R. Widodo, Sulistiono, Niken T.M. Pertiwi. 2018. Struktur Komunitas Fitoplankton di Perairan Muara Sungai Bengawan Solo, Ujung Pangkah, Jawa Timur. Biospecies. 11(1).

Tan, Xiang, et all. 2017. Benthic Diatom Based Indices for Water Quality Assessment in Two Subtropical Streams. Frontiers in Microbiology. 8.

Tanaka, H. 2007. Taxonomic Studies of the Genera Cyclotella (Kutzing) Brebisson, Discostella Houk et Klee and Puncticulata Hakansson in the Family Stephanodiscaceae Glezer et Makarova (Bacillariophyta) in Japan. Bible Diatomol. 53, 1-205.

Teittinen, Anette et al. 2016. The roles of elevation and local environmental factors as drives of diatom diversity in subarctic streams. Freshwater Biology. 61(9), 1509-1521.

Thomas, E. J and J. John. 2010. Diatoms in Wetlands from the South-West of Western Australia: Community Structure in Relation to pH.Journal of the Royal Society of Western Australia. 93, 29-42.

Umiatun, S., Carmudi dan Christiani. 2017. Hubungan antara Kandungan Silika dengan Kelimpahan Diatom Benthik di Sepanjang Sungai Pelus Kabupaten Banyumas. Jurnal Scripta Biologica. 4(1), 61-67.

Venkatachalapathy, R., and Karthikeyen, P. 2013. Diatoms Assemblages Distribution in Cauvery Rivers, Bhavani, Tamil Nadu, India in Relation to Chemical and Physiographical
Factors. Journal of Chemical Sciences. 3(11), 55-59.

Verneuil. L., J. Silvestre, F. Mouchet, E. Flahaut, J. Boutonnet, F. Bourdiol, et al. 2014. Multiwalled carbon nanotubes, natural organic matter, and the benthic diatom Nitzschia palea: "A sticky story". Nanotoxicology. 9(2), 219229.

Vouilloud, A. A. et al., 2014. Brachysira (Naviculales, Bacillariophycaea) in Lowland Waters from Colombia. Diatom Research. 29(2), 147-163.

Vuuren, S.J.V., T.Jonathan, V.G.Carin \& G. Annelise. 2006. Easy Identification Of The Most Common Freshwater Algae. South African: northwest University Noorowes Universiteit.

Wardhana, W. 2006. Metoda Prakiraan Dampak dan Pengelolaannya pada Komponen biota akuatik. Modul pelatihan penyusun analisis dampak lingkungan. Pusat Penelitian Sumber Daya Manusia dan Lingkungan. Universitas Indonesia. Jakarta.

WHO. 1996. Total dissolved solids in Drinkingwater. Geneva: World Health Organization.

Wojtal, A. 2003. Diatoms of the Families Amphipleuraceae and Brachysiraceae from the Whyzyna Krakowsko-Cze, Stochowska Upland (S Poland). Polish Botanical Journal. 48(1), 55-61.

Wolfe, A.P. \& H.J. Kling (2001): A consideration of some North American softwater Brachysira taxa and description of $B$. arctoborealis sp. Nov. Studies On Diatoms.

Xue, Hao et al. 2019. Assessment of Aquatic Ecosystem Health of the Wutong River Based on Benthic Diatoms. Water. 11.

Yuliana., Enan M. Adiwilaya., Enang Harris., dan Niken T.M. Pratiwi. 2012. Hubungan Antara Kelimpahan Fitoplankton Dengan Parameter Fisik-Kimiawi Perairan Di Teluk Jakarta. Jurnal Akuatika. 3(2), 169-179

Zelnik, I. T. Susin. 2020. Epilithic Diatom Community Shows a Higher Vulnerability of the River Sava to Pollution During the Winter. Diversity. 12.

Salusso, M.M \& Morana, L.B. 2018. Comparative reservoir limnology in 
Juramento (Salta) and Salí-Dulce (Tucumán)

Basins in Argentina. Biologia Tropica. 66(1), 415-427. 